\title{
"We Eat Only Meat" \\ a Comparison of (Food) Cultures in Transition: Greenland and the Republic of Tyva
}

\author{
Alexander H. Reich* \\ Watson Fellowship Program \\ Grinnell College Grinnell, \\ IA 50112-1670 USA
}

Received 24.08.2014, received in revised form 15.09.2014, accepted 04.10.2014

This report compares preliminary ethnographic fieldwork conducted in 2011 in West Greenland and Tozhu District of the Republic of Tyva, Russia. Harvesting of animal products from the surrounding environment has historically been an important economic and cultural activity for indigenous Greenlanders (Kalaallit) and Tozhu. However, in recent years hunting, fishing and reindeer herding have undergone drastic changes due to political, economic, social, and environmental pressures. I report my observations of these changes by focusing on their impacts on people's food provisioning and consumption practices. In short, harvesting and consumption of traditional foods are decreasing in both Greenland and Tozhu District. This decline could be linked to the recent trend of population centralization in both locations, which locals blame on government policies. Stopping or reversing this demographic shift may be the best way to maintain the unique (food) cultures and traditional activities valued by these peoples, although addressing social influences and climate change could also play a role.

Keywords: traditional food, hunting, fishing, reindeer husbandry, climate change.

Research area: Theory and History of Culture.

\section{Introduction}

"We eat only meat," said Daniil, a rural Tozhu man. Until recent times, wild meat harvested locally was the staple for the indigenous people of both Tozhu District and Greenland. Today meat retains central nutritional and cultural value, but food patterns have greatly diversified, with varied consequences.

Herein I report ethnographic fieldwork conducted in 2011 in rural communities in West Greenland and the Republic of Tyva, Russia. In both settings, I had the privilege of living with local people, participating in the harvest and eating of local animals, and listening to people's stories. I hope my observations will contribute to the discussion of how the (food) cultures of northern indigenous peoples are shifting in a world of changing resources and climate, as well as support the idea that in-depth investigations of food provisioning, or any other particular cultural phenomenon, can serve as an entry point into studying larger social or environmental changes.

(c) Siberian Federal University. All rights reserved

* Corresponding author E-mail address: reichale@gmail.com 
To my knowledge, this research represents the first comparison of (food) cultures or environmental issues in Greenland and Tyva.

Greenland and Tyva are quite distinct; Kalaallit live at the rocky fringe of the icecap that covers most of the largest island in the world. Tyva people live in a landlocked mountain basin at the geographical center of Asia, the world's largest continent. Nevertheless, the comparison of their shared characteristics should help to illustrate similar challenges northern indigenous peoples face regarding food, daily life, and social and environmental change. My observations may also inform laypeople interested in far-off places, as both Greenland and Tyva are geographically isolated and relatively unknown in the West. ${ }^{1}$

I use the term "(food) culture" to refer to the activities and lifestyles required to access or produce food, the food consumed, and the ideas people hold about the food they eat and do not eat. My parenthetical reference to (food) emphasizes my opinion that culture and food culture are inextricably linked. At least historically, accessing and consuming food exerted a great influence upon human time use, living location, and cultural and religious events and practices. Even today, as much of the world's food becomes "faster" and less connected to place, this change in food culture is tied to changes in culture.

\section{Greenland}

Greenland (Gr: Kalaallit Nunaat) is a semi-autonomous country within the Kingdom of Denmark but receives generous welfare and financial support from Denmark. Greenland is the world's largest non-continental island $\left(2,166,086 \mathrm{~km}^{2}\right)$. It experiences an Arctic climate, except for a few protected southern valleys. People live in scattered towns mostly on the western coast, where the climate is mildest. Of the 56,615 people in Greenland, more than one quarter live in the capital, Nuuk (Statistics
Greenland 2011). Greenlanders (Gr: Kalaallit) are an Inuit people, but today many are of a mixed Inuit-Danish heritage. Approximately $88 \%$ of people in Greenland were born on the island (Statistics Greenland 2011), a number equal to those considered indigenous Kalaallit (Oslvig 2011). While fish products constitute $88 \%$ of Greenland's annual export, the larger annual subsidy from Denmark is needed to sustain the economy (Statistics Greenland 2011).

\section{Tyva}

The Republic of Tyva (Rus: Respublika Tyva, area $169,000 \mathrm{~km}^{\wedge} 2$, Ivanova et al. 2010) is one of 83 Federal subjects within the Russian Federation. At the geographical center of the Asian continent, Tyva experiences a continental climate, with large daily and seasonal ranges of temperatures (Ivanova et al. 2010). The population of Tyva is $307,925,36 \%$ of whom live in the capital Kyzyl (Russian Census 2010). Tyva, an indigenous people, are $77 \%$ of the republic's population, while ethnic Russians comprise most of the rest (Russian Census 2002). Tyva's economy has not yet recovered from its collapse after the fall of the Soviet Union (Robson 2009); many people experience poor wages and a lack of work.

Tozhu District (Rus: Raiony, area 44,000 $\mathrm{km}^{\wedge} 2$ ), the hilly and forested northeastern quadrant of Tyva, is home to the Tozhu, one of the official "Indigenous Small-Numbered Peoples of the North" (Rus: Korennye Malochislennye Narody Severn), and an underprivileged indigenous minority within a republic dominated by the indigenous (but not small-numbered) majority Tyva people (Donahoe 2004). According to the 2002 Russian Census, 4,442 people are ethnically Tozhu. The Russian government defines Tozhu District as a "District of the Far North" (Rus: Raionov Krainego Severa), a characterization based upon its extreme ecological and climatic conditions and difficulty of access, which lead 
to high costs of providing for the basic needs of the population. Due to this characterization, all inhabitants are entitled to certain privileges: higher salaries in the state sector, lower retirement age, and the "northern delivery" (Rus: severnyizavoz), which provides priority access to fuel and other basic necessities (Donahoe et al. 2008). Tozhu traditionally practiced the Sayan type of reindeer herding, in which they rode reindeer to be able to range farther while hunting and fishing. However, as I later discuss, reindeer husbandry has declined in the past 20 years (Donahoe 2004, Daniil, pers. comm. 4 Nov. 2011).

\section{Methods}

This paper documents preliminary fieldwork conducted in 2011 when I lived in households and accompanied local people on hunting and fishing trips in Uummannaq District (Gr: Kommunia) in Greenland and Tozhu District (Rus: Raiony) in the Republic of Tyva. I was in Greenland July 1- Sept. 21 on the west coast. I spent time in the town of Uummannaq (ca. $70 \mathrm{deg}$. N, pop. ca. 1300), in the nearby settlement of Qaarsut (pop. ca. 180) living with a Greenlandic family, and on a 2-week $2000 \mathrm{~km}$ expedition in small speedboat to Savissivik (ca. $76 \mathrm{deg}$. N, pop. ca. 60 ), stopping at settlements along the way. While in Russia Oct. 12- Dec. 14, I spent time in the city of Krasnoyarsk- in Krasnoyarsk Krai (Province)and in the Republic of Tyva (Oct. 29- Dec. 1). In Tozhu District I lived with a family and spoke with officials and townspeople of Toora-Khem (ca. $52 \mathrm{deg}$. N, pop. 2,727). I also went on a two week (Nov. 11-27) mixed subsistence-commercial hunting and fishing trip with two Tozhu men in the boreal forest (Rus: taiga) south of the nearby settlement Adyr-Kezhig (pop. ca. 1,200). We inhabited an unoccupied winter campsite of reindeer herders, from which we hunted for sable (Rus: sobol) and fished for grayling (Rus: kharius).
The majority of my information came from my hunting companions and the families with whom I lived, especially a 47 year-old full-time Greenlandic hunter-fisherman (whom I call "Appa") from Qaarsut, and a 55 year-old Tozhu hunter-fisherman (whom I call "Daniil") from Toora-Khem who also does construction work outside of the hunting and fishing seasons. Both men had extensive experience on the land. Appa has lived his entire life in Qaarsut. Daniil was born in the taiga while his parents were herding reindeer and spent his childhood and a number of years in the 1980s as a nomadic reindeer herder and hunter. His children maintain their herd today. While I learned the basics of both the Greenlandic and Russian languages, my rudimentary abilities represent the greatest limitation to my research. In addition, Russian was Daniil's second language.

My presence as a foreign visitor unavoidably changed the behavior of the people of Qaarsut and Toora-Khem. However, my hope was for the people with whom I was living to modify their typical patterns as little as possible. To this end, I avoided using questionnaires and other academic research tools and hoped to be seen as a visitor interested in their ways of life, rather than as a professional investigator. Because of this, my results cannot be generalized to most people or regions of Greenland or Tyva. When I use the terms "Greenland" and "Tyva" to present the results of my study, I do so for the sake of brevity.

\section{Results and Discussion}

Harvesting animal products has historically been an important economic and cultural activity for indigenous Kalaallit and Tozhu. However, in recent years hunting, fishing, and reindeer herding have undergone drastic changes due to political, economic, social, and environmental pressures. First, I discuss the seasonality of life in both locations. Then, beginning with Greenland, 
I elaborate on my observations of hunting and fishing methods, post-harvest use of animals, and how these relate to identity. In the next section I focus upon food today. Finally, I comment upon environmental influences.

Daniil and Appa described similar lifestyles that vary with the seasons as different animals become accessible. Daniil fishes April-May, works in his family garden June-Sept., and hunts and fishes Sept.-Dec. In addition, he builds homes Jan.-March -when it is "too cold to go hunting or fishing"- and June-Aug. Appa works year-round solely as a hunter-fisherman. They both explained that while hunting and fishing could provide some food and money, the money was insufficient to cover total living costs. Thus, both men's wives work for wage employment in town, a common practice. A 2002 survey found that $46 \%$ of Kalaallit age 18 and older reported that their fathers were hunterfishermen, with $36 \%$ reporting their fathers as salaried employees, whereas $42 \%$ reported their mothers as homemaker-hunters' wives and $44 \%$ as salaried employees (Bjerregaard et al. 2003). Appa corroborated these numbers; 36 Qaarsut men (roughly half) are active hunter-fishermen today.

\section{Greenland}

\section{Hunting}

I went with residents of Qaarsut on subsistence hunts for ringed seal (Gr: natseq), caribou (Gr: tuttu), and muskox (Gr: umimmak), as well as numerous marine birds. People also occasionally hunt narwhals and other whales. We hunted seal from a boat while the animals were in the water or on an iceberg. Although we hunted musk ox and caribou on foot, boat journeys of ca. five hours were required to reach land inhabited by these animals. When I asked on whose territory we hunted, I was told that no individuals own private land in Greenland; every outdoor location is available for all to use. Hunters explained that they had a single license, acquired locally in Uummannaq, which allowed them to hunt and fish for a number of species. Despite being hunted opportunistically when seen, most birds were not included under the license, so people concealed them when we approached settlements.

None of the harvested animals was sold commercially, although hunters can sell to local markets (Gr: kalaalimineerniarfit). Caribou and musk ox are rare, and are eaten at home or distributed among community members. People as well as sled dogs eat seal. Historically, Kalaallit were subsistence hunters, but today the meat does not seem essential, as imported subsidized food is available at stores in every town and settlement. Nevertheless, in Qaarsut people tend to prefer "traditional" meat and continue to hunt for cultural reasons. I did not compare the cost of meat from the store with the cost of acquiring an equivalent amount of meat by hunting. However, the equipment required for hunting (rifles, bullets, boats, and gasoline) differs little from that required for fishing, so fishermen already possess most of the equipment. Many people with salaried employment also own boats, which are used not only for fishing, but also for the majority of transportation between settlements (which can otherwise only be reached by air).

Until the past few years, hunting commercially for seals for sealskin exports was one of the most important economic activities of the men of Qaarsut. Kalaallit opined that commercial sealing differs greatly in Canada and Greenland; in Canada, the hunt occurs much farther south, harvests much younger seals, and typically does not involve indigenous Canadians. Approximately 80,000 harp seals were harvested in Greenland annually between 2005 and 2008 (Statistics Greenland 2011), but in 2009 the EU voted to ban the trade of seal products. As an Inuit people residing in the Arctic, Kalaallit are 
exempted from the ban, for seal hunting has been traditionally conducted by Greenlandic people and contributes to their subsistence (Traynor 2009). However, Appa explained that the market for seal skins from Greenland has collapsed. He repeated asked me to tell Americans and Europeans that Kalaallit relied upon the seal hunt for their livelihoods, so people should return to purchasing the skins.

\section{Fishing}

In Greenland I assisted fishermen catching three types of fish primarily for commercial sale. ${ }^{2}$ All fish could be caught in Uummannaq Fiord within $10-15 \mathrm{~km}$ of Qaarsut by a single fisherman in a 4-7 $\mathrm{m}$ long open boat. The most common was long-line fishing for Greenland halibut (Gr: qaleralik) using half of a capelin (Gr: ammassat) as bait. The line is set out, left for approximately 24 hours and hauled in by hand or with a small engine. One fisherman explained that his thick nylon line had 600-700 m of length without hooks and $2500 \mathrm{~m}$ of length containing 1500 hooks. This particular line took six hours to haul in and caught 800-900 fish larger than $40 \mathrm{~cm}$ in length, a typical halibut catch. After the factory in Uummannaq stopped purchasing halibut, as the seasonal quota had been reached, fishermen set out gill nets and jigged with an unbaited lure for Atlantic cod (Gr: saarullik). Additionally, one time I assisted to retract a $500 \mathrm{~m}$ long line, baited with halibut chunks, to catch wolffish (Gr: qeeraq).

\section{Post-harvest}

Halibut, cod, and wolffish were primarily sold to the only buyer, the Royal Greenland factory in Uummannaq, where the fish were frozen and then exported by ship. Fish were also fed to sled dogs. People occasionally ate cod and wolffish fresh or gave them to friends and family. They also ate cod dried as a snack often, but always in packages purchased from Royal Greenland. In addition to these three primary commercial fish, people harvested capelin to dry for a later snack, to use as bait for halibut, or to feed to their sled dogs. Many people, including women and children, caught spawning capelin in the shallows with hoop nets on the end of sticks. A brief analysis of local perceptions about this method of fishing may illustrate some historical trends in the realms of gender, subsistence and employment.

\section{Identity}

"Fishing is for women and children," a Greenlandic man once told me. I had only ever seen one fisherwoman in Greenland, so I asked him to clarify. He noted that historically men hunted for mammals, while women and children fished for capelin from shore during the latesummer spawn. Since modern Greenlandic fishing is now a major source of income and requires boat trips, long lines and large nets, it may be seen as analogous to hunting, or men's work (although women and children do assist at times, such as jigging for cod). Modern methods of fishing in deep water away from shore have been practiced in Greenland for decades, so I question if this concept about gender and fishing is actually relevant today.

Two other patterns relate to these concepts of identity. First, I observed that despite being fishermen, people in Qaarsut ate only relatively small amounts of fresh fish. The ancestors of modern Kalaallit subsisted almost entirely on hunted marine and land mammals, and less so upon fish. A preference for mammal meat, as opposed to fish, may still exist today. History may also contribute to the second pattern of responses to my question about employment. If they did not have a salaried job, every Greenlandic man replied that he was a hunter (Gr: piniartoq). Not one replied that he was a fisherman (Gr: 
aalisartoq). I had observed that fishing was a much more common activity, ${ }^{3}$ so I asked why they were not fishermen. The typical response was "I am a hunter. I also fish, because I cannot only hunt anymore." Although I have only a partial understanding of the situation, it seems that many Greenlandic men face the issue that their personal identity as hunters does not fit with the more common economically feasible employment today-fishing. Future research should focus on whether self-identification changes in the coming years.

\section{Tyva}

\section{Hunting}

For two weeks, I accompanied Daniil and his friend Andrei on their fall hunt for sable, the pelts of which they sell for clothing. We had two hunting dogs to help track sable in fresh snow, but fresh snow was scarce, as were sable; five days of hunting yielded four sable. Thus, we spent most days fishing on the upper reaches of the Yenisey River. Nevertheless, hunting, especially for sable, is very common among Tozhu, for whom wild animals are the single most important economic resource, for both meat and furs (Donahoe 2004). The first week I was in Toora-Khem people reported innumerable times that, "All the men are out hunting." In spite, or perhaps because of, the ubiquity of hunting, people tend to ignore regulations. Very few Tozhu hunters with whom I spoke possessed the documents required for their firearm, to purchase bullets, or to hunt for a specific animal at a specific time and location. Some men even apologized for why I could not observe their hunting by explaining that they were, technically speaking, poachers.

Local definitions of poaching in the Tozhu District may have little to do with the legality of hunting, a trend also described in the rural southwest of Tyva (Halemba and Donahoe
2008). By ignoring the difficult task of obtaining permission from a distant office, people may concern themselves more with methods and customs locally considered proper for hunting. If the licensing process were simplified, as in Greenland, more hunters might register, and the government could gain a better idea of actual hunting pressure. Related to this, in Tozhu, as in Greenland, people are non-exclusive about property use; entitlement to resources appears to extend to anyone who undertakes the rigorous trip into the taiga, regardless of prior history (Donahoe 2006). This could help explain why Daniil was vehement that I receive an equal share of our fish, despite my paltry contribution to the catch.

\section{Fishing}

The fishing method I saw practiced most in Tozhu was pole and bobber fishing (which does not require a license) with monofilament line for grayling on the partially frozen upper Yenisey River. We fished while walking downstream on an ice fringe at the river's edge. After the river froze, we fished through natural holes where the current prevented freeze-over. In 11 days of fishing 6-8 hours each day, the three of us caught approximately $150 \mathrm{~kg}$ of grayling. We kept all the fish, even the smallest ones, which were fed to the hunting dogs. Coming from the American game management tradition, where there are size and catch limits, and having seen fish released in Greenland, I wonder if this practice is sustainable in the long run. There may be little enough fishing pressure on this part of the river that it does not matter. However, Donahoe (2006) noted that after reindeer herders build winter cabins, game animals and fish population decline drastically in the surrounding area. My observations seem to confirm this, for Daniil and Andrei often exclaimed that fish as well as sable were scarce. 


\section{Post-harvest}

As in Greenland, people had many uses for fish. Daniil and Andrei primarily brought fish home for soup, to grind into fishmeal for cutlets and dumplings, or to smash and eat frozen. They sold others to acquaintances and friends in TooraKhem, but the fish can also be sold at increasing prices to industrial buyers in Toora-Khem, Kyzyl, Krasnoyarsk and Moscow, if one can transport the fish. Additionally, they gave some fish to friends, which I did with my share.

\section{Identity}

Self-identification of male hunters may differ between Greenland and Tyva. As noted above, in Qaarsut, some men could be employed solely as hunter-fishermen. Thus, men with salaried jobs were not considered hunter-fishermen, even if they partook in those activities at times. Research from another region in Tyva concluded that cultural reasons for hunting outweigh economic considerations (Halemba and Donahoe 2008). This could be the case in Tozhu. However, Daniil and Andrei explained repeatedly that their hunting trip was work, for food and money. It seems that in Tozhu, most people cannot hunt/fish exclusively; they also need additional employment to make ends meet, if they indeed do hunt for economic or subsistence reasons. Since few, if any, hunt exclusively, perhaps it is acceptable for all Tozhu or Tyva men to consider themselves hunter-fishermen. This was highlighted later, in Kyzyl, when I explained my research to a medical student. He inquired knowingly about our methods of hunting and fishing and noted "I am also a hunter."

\section{Food today}

\section{Greenland}

As the title of this article suggests, meat is an important food in Qaarsut, even if it is complemented by other foods today. Most evenings we ate a simple soup of meat, salt, potatoes, and rice, with the occasional onion. In a 2002 survey of Kalaallit, approximately half of respondents reported that in the last year they ate a meal from their own catch at least 1-3 times/week (Bjerregard et al. 2003). Based on my experience in Qaarsut, people ate personally harvested food 4-6 times/week, although only $11.6 \%$ of respondents in the 2002 survey put themselves in this category. In agreement with previous research (Pars et al. 2001), some of the most preferred traditional food items were whale skin (Gr: mattak), crowberries, seal meat, and dried cod, although musk ox, caribou, and birds were also highly lauded.

Even though Qaarsut exports large quantities of fish, locals ate meat from birds and mammals (whale, caribou, muskox, seal) more often than fish, although they ate fish more than seal. People in Qaarsut often ate dried cod or capelin as snacks, but in Greenland daily consumption of both fish and seal has dropped, from $17 \%$ and $21 \%$ of respondents in 1993-1994 (Pars et al. 2001) to $8.9 \%$ and $6.4 \%$ in 1997-2001 (Bjerregaard et al. 2003). The greater decrease in consumption of seal may reflect part of the shift from sealing to fishing.

In Qaarsut people also consumed much imported food. In the morning and at midday, people had sugary cereals or bread and spreads. Potatoes, white rice, and wholegrain or rye bread were the store-bought staples. Fruit and fresh or frozen vegetables were available and many people ate some every day. Cookies and candies are popular, typically eaten with tea, coffee, and sugar during daily visits with friends. Also popular are fruit juices and soft drinks, which may contribute to a problematic food-related trend I discuss below.

With regard to food choices, Kalaallit face an unfortunate situation that I believe is already problematic for their physical and cultural 
health. In both the 1993-1994 (Pars et al. 2001) and 1997-2001 (Bjerregard et al. 2003) surveys, younger people ate traditional food less often than older people. The youngest people surveyed in 2001 would now be 28 . I observed that people of that age ate greater quantities of traditional food than youth and children. Thus, the trend of decreasing traditional food appears to continue today. However, it is also possible that these data simply reflect the Greenlandic equivalent of a trend termed "growing into subsistence," noted among Inuit in Canada. As they age, Canadian Inuit increase their hunting practices (Condon et al. 1995) and consumption of traditional food (Lougheed 2010). If consumption of traditional food is decreasing in Greenland, it is problematic because harvesting and traditional food play a central role in Greenlandic culture and provide more healthy nutrients and less unhealthy fats and sugars than the imported foods with which they are typically replaced. From a nutritional health perspective, Kalaallit should try to maintain these traditional sources of nutrition and minimize unhealthy imported foods, or food-related health issues could become as problematic as in Nunavut (Chan et al. 2006; Lougheed 2010; Nunavut Department of Health and Social Services 2007). Many Kalaallit seemed worried about the increase in imported food and spoke of the importance of maintaining consumption of traditional foods. Unfortunately, contaminants from industry and agriculture worldwide migrate to the Arctic and bioaccumulate in the animals Kalaallit eat as traditional foods, which may cause health problems when consumed. Very few Kalaallit with whom I spoke were aware of contamination in harvested food. Correspondingly, Pars et al. (2001) found that only $1 \%$ of respondents stated that fear of contaminants influenced how often they consumed traditional food. Thus, it seems unlikely that fear of contaminants alone will cause traditional food consumption in Greenland to decrease.

Greenland should create programs to support traditional food consumption. Based on my limited experience in Greenland, I believe that the cultural value of harvesting activities that are tied to the local environment and the nutritional benefits of traditional food outweigh the negative health impacts of contaminants in the food. Urbanization and modernization in Greenland are shifting food patterns such that consumption of traditional food by Kalaallit may continue to decrease if no interventions are implemented (Pars et al. 2001). Thus, Greenland should develop policies and programs to support the continuation of traditional food practices. One way to do this could be to maintain the population of Kalaallit who live in villages, as my personal experience and the literature (Pars et al. 2001) suggest that residence in a village is a predictor of traditional food consumption. Many Kalaallit from villages complained that the government was purposefully making life difficult in the villages with the intent of causing migration to the towns, where the needs of people could be more easily provided. People claimed that the major tool used by the government was the retraction of a one-price policy for the entire country, so that goods in the northernmost villages now cost 2-3 times more than in towns. Kalaallit from both villages and towns expressed to me that "Greenland becomes more Greenlandic as you go north," and that the capital, Nuuk "is not Greenland" due to the prevalence of the Danish language and the replacement of traditional Greenlandic activities with Danish ones. Thus, many Kalaallit place Greenland's cultural heart in the villages, especially the northern ones. By reinstating the one-price policy, Greenland could help to maintain not only the health of its people, but also its unique culture. An additional method to support the rural Greenlandic economy could 
be to promote tourism in villages. While tourism has certain negative effects, including the exacerbation of climate change through carbon emissions from air travel, people in Qaarsut generally seem to support it, and it plays an important role in the economies of some towns. One resident maintains a "Tourism Qaarsut" webpage, but the idea is still in its infancy.

\section{Tyva}

As in Greenland, wild-caught meat played a large role in people's lives. One morning in town, we ate bear and frozen bear fat in the same manner as meat is eaten in Greenland: by holding the meat with teeth and one hand and slicing with the other. However, most mornings and evenings on the hunting and fishing trip we consumed soup made of grayling with salt and pasta. We also had sable and grouse soup. For our two-week trip, Daniil brought pasta, salt, fried dough balls, candies, tea, milk powder, and a small amount of sugar. Before each meal, my hosts threw a spoonful from the meal towards the river, into the fire, and towards the forest, explaining that the river provided the food and water, the fire cooked the meal, and the forest fed the fire. Thus, the spirit (Tyvan: cher eeleri) in each location should receive the first food.

In contrast to Greenland, food-health developments in Tozhu may on the whole be neutral. While historically Tozhu herded reindeer and hunted instead of tending gardens, Daniil explained that recently people have begun to garden more. He perceived the increase in vegetables as positive, although he declined my offer of a beet ("That's Russian food. Only Tyva women like that") and fruit ("That's empty. Have meat or tea instead"). The health effects of gardens may be positive, as homegrown food can contain substantial nutrients. However, by practicing a typically Russian activity and increasing consumption of typical Russian garden foods, the distinct Tyva or Tozhu culture may be changing, potentially contributing to decline in the local language.

Both Tyva and Tozhu people expressed views about the Republic of Tyva that support this idea. They recited a saying: "Seen Tozhu, seen Tyva. Haven't seen Tozhu, haven't seen Tyva." When I asked for clarification, people explained that "Tozhu is the heart of Tyva." Even though Tozhu people are recognized officially as an ethnic group distinct from Tyva people, the Tyva seem to consider the Tozhu as "extra Tyva." In Kyzyl I stayed with a Tyva family that spoke only Russian at home. The 23 year-old daughter, who could understand but not speak the Tyva language, thought that approximately $40 \%$ of Tyva familes in Kyzyl spoke only Russian at home. As an urban family less able to practice traditional activities of rural Tyva, they may have become "less (or more modern) Tyva," just as Kalaallit in Nuuk were "less Greenlandic."

While changes in food in Tozhu may not create health problems in the near future, I believe the government of Tyva or Russia should still make efforts to support reindeer herding, a declining traditional activity that is still a vital facet of the Tozhu economy and ethnic identity (Donahoe 2004). I did not spend much time with active reindeer herders, but I spoke extensively with Daniil about his life and family as well as the trends in Tozhu. Some people (Robson 2010) claim that nomadism is resurging in the Republic of Tyva after the demise of the Soviet Union, when people were settled and herding was collectivized. For certain districts it may be true. However, my experience suggests the opposite regarding reindeer nomadism in Tozhu, the only district it is practiced in Tyva. Daniil remarked that the post-Soviet government has also not supported herding, claiming that at the end of the Soviet Union in 1991, Tozhu was home to approximately 17,000 reindeer. Today, he believes 
only 1,000 remain. The collapse of the state farm (Rus: sovkhoz) system, the establishment of the Russian Federation within the Commonwealth of Independent States (CIS), new constitutions at both the federal and republic levels, and measures to encourage privatization all influenced the collapse in husbandry (see Donahoe 2004 for a more complete discussion). The decrease in reindeer herding camps is analogous to the population retraction from villages to towns in Greenland, for ex-herders settle in towns in Tozhu. Donahoe noted that the unique Tozhu dialect of the Tyva language may be on the wane (Donahoe 2006), a trend which could be linked to the loss of unique Tozhu cultural activities.

It is also possible that the decrease in reindeer husbandry, combined with a lack of other economic opportunities, has contributed to the over-harvesting of key forest products near to towns (also noted by Donahoe 2004). As more people move to towns but still rely in part economically or culturally upon the taiga, use of the forests near to the towns increases. Daniil commented that just 2-3 years ago, he could hunt for sable on foot from Toora-Khem, returning home in the evening. Now, he needs to drive away from town to an area with animals. Even so, Daniil, Andrei and other hunters we met commented on the extremely low numbers of sable in the area where we hunted. They explained that in previous years they had hunted from the back of a reindeer, which allowed them to range much farther into the taiga, distributing the hunting pressure more evenly. On our trip, Daniil often expressed a wish for reindeer, pointing to hills in the distance and exclaiming "There are a lot of sable THERE!" I do not have enough experience to suggest precise policies that can support herding today, but Donahoe (2004) makes six suggestions that can help Tozhu to gain greater control over their lands and natural resources and to design and implement their own institutions of self-governance, which he states are essential if the Tozhu "are to stand any chance of genuine cultural survival." Future research should focus on the direction of developments and should modify Donahoe's suggestions, based on the new information, to help revive reindeer-facilitated hunting in Tozhu, for it represents a unique and relatively sustainable land-use, lifestyle, and cultural activity.

\section{Climate Change}

In addition to the influences discussed above, climate change is affecting both Greenland and Tyva. In Greenland, it is fundamentally altering livelihoods and cultural activities. In Tozhu the effects seem less certain, although my research there is limited.

\section{Greenland}

Although climate change may have a few positive effects in Greenland, people in Qaarsutare keenly aware of it and reported overwhelmingly that its net influence on traditional livelihoods and (food) culture has been negative. Fishermen reported the only positive effect of any significance that I heard: they catch more cod every year, as the fish range farther northward with warming ocean waters. However, the dramatic decline in the annual presence of sea ice far outweighs any benefits from increased abundance of cod. People stated that 5-10 years ago, Uummannaq Fiord was ice-covered for roughly 5 months. Last year, there was ice for 5 weeks. Without regular sea ice, people cannot hunt, fish, or use dogsleds as transport in the winter. Many Kalaallit have reduced the size of their dog packs by half, and some young hunter-fishermen are choosing not to raise dogs at all. Numerous people expressed concern that the decrease in dogsledding constitutes a loss of their culture. Boats have increased as a mode of transport, although during the now extended and unpredictable freeze-up and thaw periods, they 
are not useful either. Locals claim the weather is now more unpredictable year-round, as are animal migration patterns and abundance. As hunting and fishing become more difficult, traditional foods become less available, eroding the unique (food) culture of Kalaallit.

\section{Tyva}

Few Tozhu people with whom I spoke, including Daniil, knew about climate change. Even so, Daniil reported local changes he has observed. Recent winters have had less snow, which makes herding reindeer more difficult because the animals stray farther in search of food. Correspondingly, Robson (2009) reports that satellite measurements show a decrease in snow cover in the past 30 years, with rainfall also becoming less frequent, more erratic, and more intense. Other recent trends in Tyva are also likely caused by climate change: greater intensity and severity of forest fires (Ivanova et al. 2010), increasing volume and flooding of rivers, and more people infected by tick-borne encephalitis (Robson 2009). Since these changes manifest themselves in the spring and summer, they were not a topic of current conversation while I was in Tyva. In conclusion, while Kalaallit are experiencing climate change firsthand, Tozhu people may be less aware of the global phenomenon and seem unconcerned. If climate change impacts are more event-driven in Tyva, they may be harder for Tozhu to perceive. Regardless, if current climate-related trends continue, problems in Tyva could increase.

\section{Conclusion}

In this paper I reported on preliminary ethnographic fieldwork, using food and hunting and fishing as a way of looking at cultural and environmental changes. While West Greenland and the Tozhu District in the Republic of Tyva are very different, the indigenous populations in each find themselves in remarkably similar circumstances. Both come from a history of close relationships with harvested and working animals: sled dogs in Greenland and reindeer and hunting dogs in Tozhu. But in both locations, many people have abandoned their more traditional lifestyles and moved from rural villages to towns in Greenland and from herding camps to villages in Tozhu. Local people in both places expressed that government policies are one of the major causes of these trends, which many view as detrimental to their culture. Thus, political changes can help to preserve the unique and traditional (food) cultures of these two northern peoples, and future research should concentrate on how to best make those changes. However, government policies exist only within a natural and a social environment. In Greenland, climate change and contaminants complicate the situation, while climate change may be exerting as-yet unrecognized influences in Tozhu. In both locations, technology, motorized transport, and globalizing social influences also affect the situation. The lifestyle changes described here impact (food) culture in Greenland and Tyva in a manner that may contribute to health problems and a loss of unique local traditions. Future research should focus upon these topics, and longer-term, global-scale efforts should work to mitigate climate change before it contributes to further erosion of the unique cultures and traditions of people living in a rapidly changing north.

\section{Acknowledgements}

I would like to thank O.J. Hammeken and A. Andreasen for hosting me at the Uummannaq Polar Institute, Uummannaq, and N. Kopsteva for hosting me at the Siberian Federal University, Krasnoyarsk during field research. Thank you to $S$. Gladkiy, A. Cherepanov, B. Donahoe, C. Upright, A. Reich, and P. Reich for technical assistance and 
feedback. I gratefully acknowledge the people of Greenland and Tyva for allowing a stranger to intrude into their lives and make enough mistakes to learn a little. A Watson Fellowship from the
Thomas J. Watson Foundation supported my efforts. The funding agency neither rejects nor endorses the conclusions and views expressed herein.

\footnotetext{
Only one anthropologist -Brian Donahoe- has published English-language literature of any note about Tozhu.

Northern prawn is the most economically important Greenlandic fishery, with more than half of Greenland's 2008 and 2009 exports, followed by Greenland halibut and then Atlantic cod (Statistics Greenland 2011). Prawn fishing on the West coast occurs farther south, so I did not observe it.

3 In 2009 1,111 people in Greenland were employed in the fishing trade, while a mere 3 people were employed in the combined trade category of agriculture, hunting, and forestry (Statistics Greenland 2011).
}

\section{References}

1. Bang, H.O., J. Dyerberg and H.M. Sinclair. 1980. The composition of the Eskimo food in north western Greenland. The American Journal of Clinical Nutrition 33: 2657-2661.

2. Bjerregaard, P., T. Curtis, K. Borch-Johnsen, G. Mulvad, U. Becker, S. Andersen and V. Backer. 2003. Inuit health in Greenland: a population survey of life style and disease in Greenland and among Inuit living in Denmark. International Journal of Circumpolar Health 62 suppl. 1: 3-79.

3. Chan, H.M., K. Fediuk, S. Hamilton, L. Rostas, A. Caughey, H. Kuhnlein, G. Egeland and E. Loring. 2006. Food security in Nunavut, Canada: barriers and recommendations. International Journal of Circumpolar Health 65(5): 416-431.

4. Condon, R.G., P. Collings and G. Wenzel. 1995. The Best Part of Life: Subsistence Hunting, Ethnicity, and Economic Adaptation among Young Adult Inuit Males. Arctic 48(1): 31-46.

5. Donahoe, B. 2004. A Line in the Sayans: History and Divergent Perceptions of Property Among the Tozhu and Tofa of South Siberia. Unpublished Ph.D. dissertation, Indiana University Department of Anthropology.

6. Donahoe, B. 2006. Who owns the taiga? Inclusive vs. Exclusive Senses of Property among the Tozhu and Tofa of Southern Siberia. Sibirica 5(1): 87-116.

7. Donahoe, B., J.O. Habeck, A. Halemba and I. Seántha. 2008. Size and Place in the Construction of Indigeneity in the Russian Federation. Current Anthropology 49 (6): 993-1020.

8. Federal State Statistics Service. 2004. Population of Russia, its federal districts, federal subjects, districts, urban localities, administrative centers, and rural localities with population over 3,000. All-Russia Population Census of 2002 (in Russian). Federal State Statistics Service. <http:// www.perepis2002.ru/index.html?id=87>. Accessed 5 Dec. 2011.

9. Federal State Statistics Service. 2011. Preliminary results of the 2010 All-Russian Population Census (in Russian). Federal State Statistics Service. <http://www.perepis-2010.ru/results_of_the_ census/VPN-BR.pdf >. Accessed 5 Dec. 2011.

10. Greenland in Figures 2011. Statistics Greenland. <http://www.stat.gl/dialog/main.asp?lang=e $\mathrm{n} \&$ version $=2011 \&$ link $=$ GF\&subthemecode $=01 \&$ colcode $=0>$. Accessed 4 Dec. 2011.

11. Greenpeace. 15 Dec. 2009. How did these fish end up on the Red List? Greenpeace International. $<$ http://www.greenpeace.org/international/en/campaigns/oceans/seafood/red-list-of-species/how-onthe-red-list/>. Accessed 9 Dec. 2011.

12. Halemba, A. and B. Donahoe. 2008. Local perspectives on hunting and poaching. Research report for WWF Russia Altai-Saian Ecoregion, 1-33. 
13. IUCN 2011. IUCN Red List of Threatened Species. Version 2011.2. <www.iucnredlist.org>. Accessed 9 Dec. 2011.

14. Ivanova, G.A., V .A. Ivanov, E.A. Kukavskaya and A.J. Soja. 2010. The frequency of forest fires in Scots pine stands of Tuva, Russia. Environ. Res. Lett. 5: 1-7.

15. Kuhnlein, H.V., O. Receveur, R. Soueida and G.M. Egeland. 2004. Arctic Indigenous Peoples Experience the Nutrition Transition with Changing Dietary Patterns and Obesity. Community and International Nutrition 134(6): 1447-1453.

16. Lougheed, T. 2010. The Changing Landscape of Arctic Traditional Food. Environ. Health Perspect. 118: a386-393.

17. Nunavut Department of Health and Social Services. 2007. Nutrition in Nunavut: A Framework for Action. Department of Health and Social Services, Government of Nunavut, Iqaluit. $<$ http://tinyurl. com/26n95j6>. Accessed 5 Dec. 2011.

18. Oslvig, S. 2011. Greenland. In Wessendorf, K. (ed.). The Indigenous World 2011. IWGIA, Copenhagen, 22-28.

19. Pars, T., M. Osler and P. Bjerregaard. 2001. Contemporary Use of Traditional and Imported Food among Greenlandic Inuit. Arctic 54(1): 22-31.

20. Robson, A. Dec. 2009. Shamans don't want to be rich. Le Monde Diplomatique: LMD English edition exclusive. $<$ http://mondediplo.com/2009/12/08tuva >. Accessed 5 Dec. 2011.

21. Robson, A. 2010. Balancing Act: Biocultural Diversity Tuva. Resurgence Magazine 258: 4849.

22. Traynor, I. May 5, 2009. Europe votes to ban seal product trade. The Guardian. $<$ http://www. guardian.co.uk/environment/2009/may/05/eu-bans-seal-products $>$. Accessed 9 Dec. 2011.

\title{
«Мы едим только мясо». \\ Сравнительный анализ (пищевых) культур \\ в переходном периоде: \\ Гренландия и Республика Тува
}

\author{
Александр X. Райх \\ Стипендиат фонда Watson: Колледж Гриннель, \\ Гриннель, ІА 50112-1670, США
}

В данной статье представлен сравнительный анализ предварительных этнографических полевых исследований, проведенных в 2011 году в Западной Гренландии и в Тоджинском кожууне Республики Тыва, Россия. Заготовка продуктов животного происхождения из окружающей среды исторически являлась важным видом экономической и культурной деятельности коренных народов Гренландии (Калааллит) и Тоджинского кожууна. Тем не менее, в последние годы охота, рыболовство и оленеводство претерпели кардинальные изменения в связи с политическим, экономическим и сочиальным давлением, а также ухудшением экологической обстановки. В статье представлены мои наблюдения этих изменений. Особое внимание уделяется их воздействию на практику заготовки продуктов и их потребление среди населения. В иелом, мною было отмечено сокращение заготовки и потребления традиционных 
продуктов питания, как в Гренландии, так и в Тоджинском кожууне. Такое сокращение может быть связано с недавней тенденцией к централизации населения, в чем местные жители обвиняют государственную политику. Попытки остановить или повернуть вспять этот демографический сдвиг могут стать лучиим способом сохранить уникальные (пищевые) культуры и традиционных виды деятельности, которые ценят эти народы, хотя решение проблем социиального влияния и климатических изменений также может сыграть свою роль.

Ключевые слова: традищионная пища, охота, рыболовство, оленеводство, климатические изменения.

Научная специальность: 24.00.01 - теория и история культуры. 